HABITAT, 32 (2), 2021, 82-92

DOI: 10.21776/ub.habitat.2021.032.2.10

\title{
Price Integration Analysis of Crude Oil and Vegetable Oils
}

\author{
Resti Prastika Destiarni ${ }^{1^{*}}$, Ahmad Syariful Jamil ${ }^{2}$ \\ ${ }^{1}$ Department of Agribusiness, Faculty of Agriculture, University of Trunojoyo Madura, Jl. Raya Telang, \\ PO BOX 2, Kamal, Bangkalan, Indonesia \\ ${ }^{2}$ Jambi Agricultural Training Center, Ministry of Agriculture, Jl. Jambi - Palembang KM 16, Pondok \\ Meja, Mestong. Jambi, Indonesia
}

Received: 1 February 2021; Revised: 21 June 2021; Accepted: 22 June 2021

\begin{abstract}
The importance of palm oil as Indonesia's main export commodity from the non-oil and gas sector makes a study about the price integration of crude oil and vegetable oils is conducted. The time-series data is used are monthly data from 2002:2 to 2019:4. Using the Vector Correction Model (VECM), this study aimed to analyze the price integration among Log of Crude Oil Price (LCOP), Palm Oil Price (LPOP), Soybean Oil Price (LSOP), Sun Flower Oil Price (LSFOP) and Rapeseed Oil Price (LROP). Augmented-Dickey Fuller (ADF) stationary test results show that the time series for those data are stationary at first difference. Using the Pearson Correlation test among price data indicates that there is a high positive correlation among those price data. It reveals a high degree of short-run integration among oil price data. Based on the Johansen cointegration test, the result reveals the presence of long-run relationships among determinants. Knowing presence of cointegration among the data, a bivariate cointegration test was conducted in this study. The test showed that LCOP did not have long-run relationship with vegetable oil prices. The Engel Granger Causality test revealed that generally, LPOP have influence on the movement both LCOP and other vegetable oil prices.
\end{abstract}

Keywords: causality; cointegration; price; vegetable; oil

\section{How to cite:}

Destiarni, R. P., \& Jamil, A. S. (2021). Price Integration Analysis of Crude Oil and Vegetable Oils. HABITAT, 32(2), 82-92. https://doi.org/10.21776/ub.habitat.2021.032.2.10

\section{Introduction}

Vegetable oil is one of the important commodities in the world trade of food oil (Aji, 2010; Paramita et al., 2015). This is supported by an increasing in world demand for vegetable oils (Rifai et al., 2017). In 2013, world vegetable oil needs reached 162.8 million tons and increased by 3.1 percent compared to 2012 which only reached 157.9 million tons. In 2030, world vegetable oil needs are estimated to increase by 315.2 million tons, which one of the reason is due to world population growth and the shifting of energy resources from fossil energy to renewable energy, is called biofuel (Rifai et al., 2017). In the world market of vegetable oil, there are four types of vegetable oils that are widely consumed by residents throughout the world, they are soybean oil, sunflower oil, rapeseed oil, and crude palm oil (Paspi, 2018a). Based on USDA data in the results

${ }^{*}$ Correspondence Author.

E-mail: resti.destiarni@trunojoyo.ac.id

Phone: +62 878870211140 of research by the Paspi Research Team (2018), the total area of the four vegetable oil-producing plants in 2017 reached 208 million hectares with the largest proportion coming from soybean commodities with a planting area of 126 million hectares (61 percent) (Paspi, 2018a). Although soybean commodities have the widest planting area, oil palm is the largest vegetable oil producer in the world. The area of oil palm plantations is only 21 million hectares (10 percent) but can produce 73 million tons of oil or 42 percent of the world's four major vegetable oils total production.

The high production of palm oil is influenced by the high level of oil palm productivity which is equal to 4.27 tons/ha while other vegetable oil producing plants only have a productivity of around $0.4-0.6$ tons/ha. The amount of palm oil production which is greater than other vegetable oils has an impact on the formation of lower palm oil prices than other vegetable oils. According to PASPI (2018) that since 2000, CPO prices have been lower than the prices of soybean oil, sunflower oil, and rapeseed oil historically. Basically, the low price of palm oil 
is a competitive advantage for palm oil because it can be the main choice of vegetable oil for developing countries around the world which is compared with other vegetable oils whose prices are relatively more expensive (Paspi, 2018b). Palm oil producers in the world are controlled by two countries, they are Indonesia and Malaysia. Since 2006, Indonesia has succeeded in becoming the largest producer of palm oil in the world and later in 2009, palm oil has surpassed the dominance of soybean oil in the world vegetable oil market which has resulted for Indonesia's position as an important role in the world vegetable oil market because of Indonesia is the largest producer of palm oil in the world today. Recently, palm oil producers are faced with fluctuations palm oil price with a downward trend. In the 2018, the price of world palm oil has decreased by 2 percent an average per month. In January 2018, the price of palm oil is USD 703.45 then decreased to USD 656.50 in May and closed at USD 535.02 in December. Even though palm oil prices tend to be cheaper than other vegetable oils, but the downward trend in palm oil prices raises anxiety for palm oil businesses.

Price is one of the variables that affect the trade of an item or service, especially products that are traded internationally because it will be the basis for buying and selling between countries. Nearly 70 percent of Indonesia's palm oil production is an export commodity, making this commodity the largest strategic commodity and foreign exchange contributor to Indonesia in the non-oil and gas sector (Paspi, 2018a). Fluctuations in palm oil price with a downward trend can be influenced by the price fluctuations that occur in other vegetable oil commodities that are competitors and substitute products of palm oil. In addition, the movement of crude oil prices can also affect the fluctuations in world palm oil prices. Given the importance of palm oil as Indonesia's main export commodity from the non-oil and gas sector, a study of the integration of the prices of crude oil and vegetable oils is made consisting of palm oil, sunflower oil, soybean oil, and rapeseed oil.

The research about crude palm oil has developed widely which is one of the topics is about price integration which is integrated with crude oil, other vegetables oil, and agriculture products. The research which was conducted by Bergmann, et. al (2016) showed that world butter and palm oil prices also the volatility are affected by crude oil prices which is the highlights the important role of oil as an input factor of agriculture (Bergmann et al., 2016). Besides that, Rosa, et al. (2014) showed that there was cointegration between crude oil price and agriculture commodities represented by corn and soybean because of the large use of energy intensive inputs and also the use of biofuel in production (Rosa et al., 2014).

Fadilla (2014) revealed that crude oil prices has a long term effect on CPO prices which there was a shock on crude oil prices will be responded positively by $\mathrm{CPO}$ so that when crude oil prices increased, so did CPO prices (Fadila et al., 2014). In Indonesia, international CPO prices will affect on domestic CPO prices because actually Indonesia has no bargaining power to control both local and international prices so that the government enacted export tax policy on this commodity although the overall impact was still insignificant but it can reduce domestic CPO prices instability (Manurung et al., 2019). It was also showed in the previous research that international $\mathrm{CPO}$ price affect domestic $\mathrm{CPO}$ price (Rifin, 2009). Beside that, Manik, et. Al (2018) revealed that CPO prices was integrated in short and long term with soybean oil prices so that the change on soybean oil prices will influence the change of CPO prices (Manik et al., 2018).

Songsiengchai, et. al (2008) research showed that Thailand CPO prices was influenced by Malaysia CPO prices and world crude oil prices while negatively related to soybean oil prices but it was different with other study which was referred by this research that soybean oil prices actually positively related with CPO prices meanwhile this research agreed that when the price of crude oil continued to increase and vegetable oils became source of biodiesel, the influence of crude oil on those will be raised (Songsiengchai et al., 2018, 2020). Therefore, the research about this integration price related with other vegetable oils not only soybean oil because there are an increasing consumption trend in other vegetable oils such as rapeseed oil.

\section{Research Methods}

The main data which is used in this study are monthly data consisting of the Log of Crude Oil Price (LCOP), Palm Oil Price (LPOP), Soybean Price (LSOP), Sun Flower Oil Price (LSFOP) and Rapeseed Oil Price (LROP). Those data were collected from various sources such as the World Bank, Central Bureau of Statistics and Indonesia Ministry of Agriculture ranging from 
February 2002 till April 2019. The selection of those data was based on a presumption of existence causal relationship among the data; therefore, Vector Error Correction Model (VECM) was conducted to address the objective.

Vector Error Correction Model (VECM) has widely used for examining complex multivariate systems, because it is easy and intuitive interpretation (Barrett \& Li, 2002). VECM is restricted Vector Autoregression (VAR) form, this restriction is imposed to avoid the existence of nonstationary data while it is cointegrated. VECM develops model simultaneously in a complex single system (multivariate), so it can reveal causal relationships among variables in the equation. Co-integrated among price series suggest that two prices may behave in different way in the short-run, but will converge towards a common behavior in the longrun (Barrett \& Li, 2002). The characteristics of the dynamic relationship among the prices can be further described by VECM (Barrett \& Li, 2002).

In this study, VECM was used in order to 1) Impulse response functions (IRF); this tool was used to trace present and future responses of each variable to the shock of the variable itself and other variables. IRF result is very sensitive to the ordering of variables that are used in the calculations in which this study was based on Cholesky factorization (Buyung et al., 2017); 2) Forecast Error Decomposition of Variance (FEDV); this tool was used to forecast variance contribution in the percentage of each variable to a change of another variable and 3) Granger causality; this tool was used to examine the relationship among variables.

Before estimating VECM, there are three steps used in this study, 1) unit root test; this method was used to examine whether the price series are stationary and are requirement before processing to cointegration analysis. Augmented Dickey-Fuller (ADF) unit root test was applied to this study; 2) lag optimal length determination; selection criteria such as Likelihood Ratio (LR), Final Prediction Error (FPE), Akaike Information
Criterion (AIC), Schwarz Information Criterion (SIC) and Hannan-Quinn Criterion (HQC) were used in this study (Songsiengchai et al., 2018); 3) Multivariate and Bivariate Cointegration test; to test existence of cointegration among variables in this study, Bivariate and multivariate Johansen cointegration tests were employed; and 4) Granger Causality test; it was used to estimate at least unidirectional causality linkages as an indication of some degree of integration (Amna Awad Abdel Hameed \& Fatimah Mohamed Arshad, 2009).

The VECM in this study can be written as follows:

$\Delta Y_{t}=\sum_{i=1}^{k-1} \Gamma_{i} \Delta Y_{t-i}-\gamma \beta Y_{t-1}+\varepsilon_{t}$

Where:

$\Gamma=$ coefficient of short term

$\beta=$ coefficient of long term

$\gamma=$ speed of adjustment

\section{Results and Discussion}

Table 1 shows the summary statistics for the crude oil and vegetable prices. During the research period, the average of world sunflower oil was the highest at $944.94 \mathrm{USD} / \mathrm{mt}$, with a minimum of 543 $\mathrm{USD} / \mathrm{mt}$ and a maximum of $2045 \mathrm{USD} / \mathrm{mt}$. In addition, the sunflower oil price was also the most volatile of oil prices with a standard deviation of 338.09. Of all vegetable oil prices, the average price of palm oil was the lowest at $740.74 \mathrm{USD} / \mathrm{mt}$ compared to other vegetable oils, with a maximum of $1377.22 \mathrm{USD} / \mathrm{mt}$ and a minimum of 352.98 USD/mt. Thus, it implies that palm oil was the most competitive vegetable oil. Except for Sunflower oil price, all of the vegetable oils had negative skew and platikurtik form consecutively based on skewness and kurtosis coefficients. Both coefficients reveal that those data were not normally distributed. It is confirmed by the Jarque-Bera coefficient; therefore, all data were transformed into a natural logarithm.

The correlation test among oil prices was examined to know the short-run integration (Sendhil et al., 2014).

Table 1. Descriptive Statistics

\begin{tabular}{lrrrrr}
\hline & Palm Oil & Rapeseed & Soybean & SunFlower & Crude Oil \\
\hline Mean & 740.74 & 901.80 & 851.94 & 944.94 & 67.33 \\
\hline Median & 719.64 & 844.71 & 824.42 & 835.17 & 62.46 \\
\hline Maximum & 1377.22 & 1591.88 & 1535.16 & 2045.00 & 132.83 \\
\hline Minimum & 352.98 & 410.77 & 359.21 & 543.00 & 19.98 \\
\hline Std. Dev & 243.12 & 252.72 & 262.14 & 338.09 & 27.41 \\
\hline Skewness & 0.62 & 0.68 & 0.55 & 1.20 & 0.27 \\
\hline
\end{tabular}




\begin{tabular}{lrrrrr}
\hline & Palm Oil & Rapeseed & Soybean & SunFlower & Crude Oil \\
\hline Kurtosis & 2.71 & 2.97 & 2.61 & 3.57 & 2.02 \\
\hline Jarque-Bera & 13.91 & 15.95 & 11.73 & 52.56 & 10.69 \\
\hline
\end{tabular}

The correlation of oil prices as shown in Table 2 reveals that vegetable oils and crude oil have a high correlation. All correlation coefficients among prices are above 80\%. Rapeseed oil and soybean have the highest coefficient which means the increasing of rapeseed oil price will be followed by the soybean oil price. Table 2 also showed the relationship between vegetable oils was higher than the relationship between vegetable oils and crude oil.

It meant that the strong substitution relationship experienced among those vegetable oils. The substitution relationship also happened on crude oil dan vegetable oils which are confirmed by Saghaian (S. Saghaian et al., 2018; S. H. Saghaian, 2010). Pokrivcak (2011) states that biofuels produced by vegetable oils are an almost perfect substitute for fossil fuels. The market price of biofuels should, therefore, be strongly dependent on the market price for gasoline and diesel (Pokrivcak \& Rajcaaniova, 2011).

Table 2. The Correlation Matrix of the Variable Prices

\begin{tabular}{lccccr}
\hline & Palm Oil & Rapeseed & Soybean & SunFlower & Crude Oil \\
\hline Palm Oil & 1.000000 & & & & \\
\hline Rapeseed & 0.938989 & 1.000000 & & & \\
\hline Soybean & 0.968851 & 0.975997 & 1.000000 & & \\
\hline Sun Flower & 0.937630 & 0.952295 & 0.951788 & 1.000000 & \\
\hline Crude Oil & 0.817605 & 0.869182 & 0.853188 & 0.801876 & 1.000000 \\
\hline
\end{tabular}

Augmented Dicky Fuller test was conducted for checking the stationarity of the variable prices. Nonstationary data will lead to spurious correlation among variables (Pokrivcak \& Rajcaaniova, 2011). Table 3 shows that at the 1st different form I (1) all the data were stationary (p-value $<0.05)$. The order of the data was referred to the number of times a variable is differenced before becoming stationary.

Tabel 3. Unit root tests

\begin{tabular}{lcrrrrrr}
\hline & \multicolumn{2}{c}{ Intercept } & \multicolumn{2}{c}{ Trend and Intercept } & \multicolumn{2}{c}{ None } \\
\hline & & t-statistic & \multicolumn{1}{c}{ Prob } & t-statistic & Prob & t-statistic & \multicolumn{1}{c}{ Prob } \\
\hline Palm Oil & Level & -2.275593 & 0.1809 & -2.07796 & 0.5545 & -0.45562 & 0.5167 \\
\hline $\begin{array}{c}1 \\
\text { difference }\end{array}$ & -6.453454 & 0 & -6.51283 & 0 & -6.46592 & 0 \\
\hline Rapeseed Oil & Level & -2.522425 & 0.1116 & -2.31053 & 0.4259 & -0.29784 & 0.5775 \\
\hline $\begin{array}{c}1 \\
\text { difference }\end{array}$ & -9.117198 & 0 & -9.174 & 0 & -9.12832 & 0 \\
\hline Soybean Oil & Level & -2.535291 & 0.1086 & -2.31086 & 0.4258 & -0.41315 & 0.5335 \\
\hline $\begin{array}{c}1 \\
\text { Sun Flower }\end{array}$ & $\begin{array}{c}\text { Level } \\
\text { Oil }\end{array}$ & -2.470985 & 0.1241 & -2.36545 & 0.3966 & -0.71292 & 0.4069 \\
\hline \multicolumn{1}{c}{$\begin{array}{c}1 \\
\text { difference }\end{array}$} & -8.690289 & 0 & -8.70802 & 0 & -8.71074 & 0 \\
\hline Crude Oil & Level & -2.586473 & 0.0974 & -2.55292 & 0.3026 & -0.61994 & 0.4478 \\
\hline & $\begin{array}{c}1 \\
\text { difference }\end{array}$ & -9.026617 & 0 & -9.02245 & 0 & -9.03486 & 0 \\
\hline
\end{tabular}


The existence of a long-run relationship among oil prices was conducted using bivariate and multivariate Johansen's cointegration test. The bivariate cointegration test results provide additional insight and were used in conjunction with the multivariate Johansen cointegration test. The result of the bivariate cointegration test is presented in Table 4. The results reveal a cointegration relationship appears among vegetable oil prices. Cointegration among vegetable oils is also found in $\mathrm{Yu}$, et al article which said that there are one long run cointegration among five oil prices including vegetables oil (soybean, sunflower, rapeseed, palm oil) and crude oil (Yu et al., 2006). The existence of long run relationship among vegetable oils showed the integration. Meanwhile, the result showed that there is no long run relationship between crude oil and vegetable oils.

Table 4. Bivariate Johansen Cointegration Test

\begin{tabular}{lrc}
\hline & \multicolumn{2}{c}{ Bivariate } \\
\hline & P-value & Null Hypothesis \\
\hline LCOP/LPOP & 0.2402 & Fail to Reject \\
\hline LCOP/LROP & 0.1286 & Fail to Reject \\
\hline LCOP/LSOP & 0.2080 & Fail to Reject \\
\hline LCOP/LSFOP & 0.0586 & Fail to Reject \\
\hline LPOP/LROP & 0.0024 & Rejected \\
\hline LPOP/LSOP & 0.0001 & Rejected \\
\hline LPOP/LSFOP & 0.0043 & Rejected \\
\hline LROP/LSOP & 0.0487 & Rejected \\
\hline LROP/LSFOP & 0.0003 & Rejected \\
\hline LSOP/LSFOP & 0.0069 & Rejected \\
\hline
\end{tabular}

The result of the Johansen multivariate cointegration test showed in Table 5. The Table 5 indicates the existence of one cointegration equation at the $5 \%$ significance level. It means one linear combination among oil prices in the long run, despite deviation from equilibrium levels in the short-run. It also implies that information flow (price transmission) occurs among the oil prices (Sinha, 2015).

Table 5. Multivariate Johansen Cointegration Test

\begin{tabular}{lcc}
\hline Hypothesized No. of CE (s) & $\begin{array}{c}\text { Trace } \\
\text { Statistic }\end{array}$ & Prob.** \\
& 82.13528 & 0.0191 \\
None* & 46.21591 & 0.2078 \\
At most 1 & 29.29416 & 0.1882 \\
At most 2 & 14.80052 & 0.2380 \\
At most 3 & 7.041555 & 0.1242 \\
\hline
\end{tabular}

After examining the cointegration, the analysis continues to examine the appropriate lag for estimating VECM. The appropriate lags of VECM estimation were determined by Likelihood Ratio (LR), Final Prediction Error (FPE), Akaike Information Criterion (AIC), Schwarz Information Criterion (SIC) and Hannan-Quinn Criterion (HQC). The test reveals appropriate lag for the model was the first lag. It was based on SC criterions. The number of lag criteria means the implication of all variable oil prices which are used in the equation influence each other not only in the same period but those variables which are interrelated to one previous periods (Buyung et al., 2017).

Tabel 6. Lag Optimal Length Based on Multiple Criteria

\begin{tabular}{rrrrrrr}
\hline & \multicolumn{1}{l}{ LogL } & \multicolumn{1}{l}{ LR } & FPE & AIC & \multicolumn{1}{c}{ SC } & \multicolumn{1}{c}{ HQ } \\
\hline 0 & -5200.856 & NA & $1.04 \mathrm{e}+18$ & 55.67760 & 55.76399 & 55.71261 \\
\hline 1 & -4255.471 & 1830.102 & $5.53 \mathrm{e}+13$ & 45.83392 & $46.35228^{*}$ & 46.04396 \\
\hline 2 & -4194.493 & 114.7829 &, $3.77 \mathrm{e}+13$ & 45.44912 & 46.39945 & $45.83419^{*}$ \\
\hline 3 & -4165.751 & 52.56586 & $3.63 \mathrm{e}+13^{*}$ & $45.40910^{*}$ & 46.79139 & 45.96920 \\
\hline 4 & -4151.077 & 26.05129 & $4.06 \mathrm{e}+13$ & 45.51954 & 47.33380 & 46.25468 \\
\hline 5 & -4125.630 & $43.81858^{*}$ & $4.06 \mathrm{e}+13$ & 45.51476 & 47.76098 & 46.42493 \\
\hline
\end{tabular}

VAR stability needs to be examined before doing extended analysis because if the VAR estimation result is combined by unstable error correction model, impulse response function (IRF) and forecasting error variance decomposition (FEDV) is invalid. The examination of VAR stabilization is conducted by using VAR stability condition check such as roots of characteristic polynomial. The VAR system is stable if all roots has a smaller modulus than one.

Table 7 shows that VAR equation has a smaller modulus than one on lag 1 so that it is concluded that the existing VAR model which is conducted has been stable on optimum lag, it is lag 1. 
Tabel 7. VAR Stability Condition Check

\begin{tabular}{cc}
\hline LogL & LR \\
\hline $0.956562-0.018050 \mathrm{i}$ & 0.956732 \\
\hline $0.956562+0.018050 \mathrm{i}$ & 0.956732 \\
\hline 0.902445 & 0.902445 \\
\hline $0.856032-0.038264 \mathrm{i}$ & 0.856887 \\
\hline $0.856032+0.038264 \mathrm{i}$ & 0.856887 \\
\hline
\end{tabular}

The result of cointegration indicates that VECM can be estimated by using the optimum lag. It was estimated to indicate the speed of adjustment to long-run changes. The robustness of the VECM model was evaluated by using the Portmanteuau autocorrelation test and the autocorrelation LM test (Songsiengchai et al., 2018). The Portmanteau and LM test tests imply the same conclusion in which we cannot reject the null hypothesis of no serial correlation up to lag 12th and there was no serial correlation in the model up to lag 12 respectively.

Tabel 8. reveals all of the ECT coefficients were negative, but only LROP and LSOP which had significant error correction term (ECT). According to Hassan and Balu (2016), the negative ECT value will show how quickly the adjustment is needed in a short run disequilibrium towards long-run equilibrium (Hassan \& Balu, 2016).

Hameed and Arshad (2009) stated that ECT value not only measured disequilibrium but also captured deviations from it (Amna Awad Abdel Hameed \& Fatimah Mohamed Arshad, 2009).

The number of ECT coefficient of LSOP implies that the speed of adjustment towards the equilibrium takes place by $0.25 \%$ per period. The insignificant ECT coefficient of LPOP implies that the changes in LPOP were not significantly influenced by LCOP, LROP, LSOP, and LSFOP or It might be influenced by other factors.

Tabel 8. Error Correction Model

\begin{tabular}{cccccr}
\hline Error Correction & D(LROP) & D(LPOP) & D(LCOP) & D(LSOP) & D(LSFOP) \\
\hline \multirow{3}{*}{ Cointegration Equation } & -0.011138 & -0.000100 & -0.000392 & -0.015059 & -0.005701 \\
\cline { 2 - 6 } & $(0.00400)$ & $(0.00520)$ & $(0.00764)$ & $(0.00394)$ & $(0.00489)$ \\
\cline { 2 - 6 } & {$[-2.78300]$} & {$[-0.01923]$} & {$[-0.05132]$} & {$[-3.82290]$} & {$[-1.16507]$} \\
\hline
\end{tabular}

VECM estimated result in the short run shows that in short run LCOP is not influenced by LPOP, LSOP, LSFOP, and LROP. Besides that, VECM model also shows that crude oil price (LCOP) is also not influenced by its own price in previous period. It is reflected by $\mathrm{p}$ value which is insignificant at $5 \%$. In the contrary, LPOP, LSOP, LSFOP, and LROP is only influenced by LCOP. Meanwhile, the vegetable oil price in previous period is influenced insignificantly the vegetable price recently. In the other words, vegetable oil prices is only influenced by crude oil price.
To give more explanation about VECM estimation, the Granger causality test was examined with a lagged error correction term where the series were cointegrated. The result of the Granger causality test is presented in Table 7.

The result shows that vegetable oil prices do Granger cause crude oil prices. In other words, it can be concluded that there was a short-run causality from vegetable oil prices significantly influenced the crude oil price in the short run.

Tabel 9. The Result of The Granger Causality Test

\begin{tabular}{lccc}
\hline \multicolumn{1}{c}{ Causal reference } & F-Statistic & Causal reference & F-Statistic \\
\hline LPOP/LCOP & $6.48142^{* * *}$ & LSOP/LPOP & 1.44442 \\
\hline LCOP/LPOP & 0.77301 & LPOP/LSOP & $6.22406^{* * *}$ \\
\hline LROP/LCOP & $3.08606^{* *}$ & LSFOP/LPOP & 1.82650 \\
\hline LCOP/LROP & 0.67202 & LPOP/LSFOP & 1.66605 \\
\hline LSOP/LCOP & $4.05602^{* * *}$ & LSOP/LROP & $7.60054 * * *$ \\
\hline LCOP/LSOP & 1.81764 & LROP/LSOP & 0.74567 \\
\hline LSFOP/LCOP & $4.34293^{* * *}$ & LSFOP/LROP & $9.44292^{* * *}$ \\
\hline LCOP/LSFOP & 0.04095 & LROP/LSFOP & 0.13954 \\
\hline LROP/LPOP & 0.30999 & LSFOP/LSOP & $4.38583^{* * *}$ \\
\hline LPOP/LROP & $4.07322^{* * *}$ & LSOP/LSFOP & 1.01772 \\
\hline
\end{tabular}

Note: $* * *=$ significant at $1 \% ; * *=$ significant at $5 \% ; *=$ significant at $10 \%$ 
Tabel 10. VECM Estimated Result

\begin{tabular}{cccccc}
\hline & D(LSFOP) & D(LSOP) & D(LROP) & D(LPOP) & D(LCOP) \\
\hline \multirow{2}{*}{ D(LSFOP) } & 0.0356421 & 0.130175 & 0.22552 & 0.108730 & 0.199966 \\
& $(0.09554)$ & $(0.07728)$ & $(0.07925)$ & $(0.10499)$ & $(0.14946)$ \\
\hline \multirow{2}{*}{ D(LSOP) } & 0.157469 & 0.447745 & 0.378715 & 0.291181 & 0.105909 \\
& $(0.13191)$ & $(0.10670)$ & $(0.10942)$ & $(0.14496)$ & $(0.20635)$ \\
\hline \multirow{2}{*}{ D(LROP) } & -0.025382 & -0.083645 & -0.003118 & -0.207644 & -0.261087 \\
& $(0.11298)$ & $(0.09159)$ & $(0.09376)$ & $(0.12430)$ & $(0.17695)$ \\
\hline \multirow{2}{*}{ D(LPOP) } & 0.008293 & -0.093825 & -0.137739 & 0.283067 & 0.280239 \\
\multirow{2}{*}{ D(LCOP) } & $(0.09668)$ & $(0.07838)$ & $(0.08023)$ & $(0.10637)$ & $(0.15142)$ \\
& -0.045276 & -0.061772 & -0.030830 & -0.093450 & 0.219022 \\
& $(0.04595)^{* *}$ & $(0.03725)^{* *}$ & $(0.03813)^{* *}$ & $(0.05055)$ & $(0.07196)$ \\
\hline
\end{tabular}
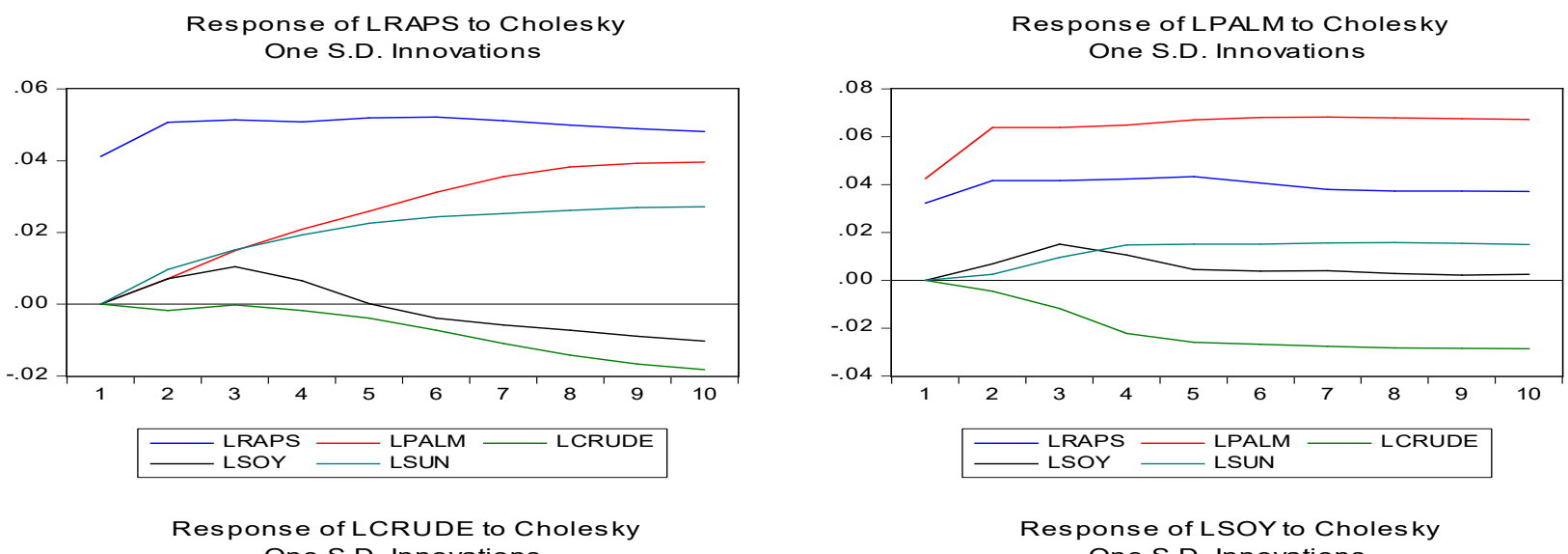

One S.D. Innovations
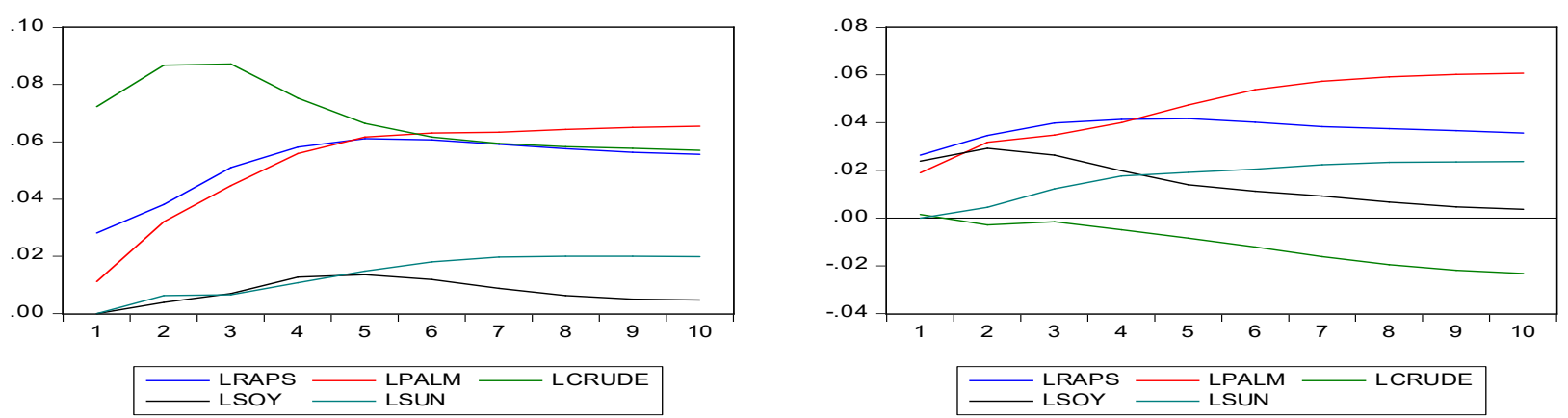

Response of LSUN to Cholesky One S.D. Innovations

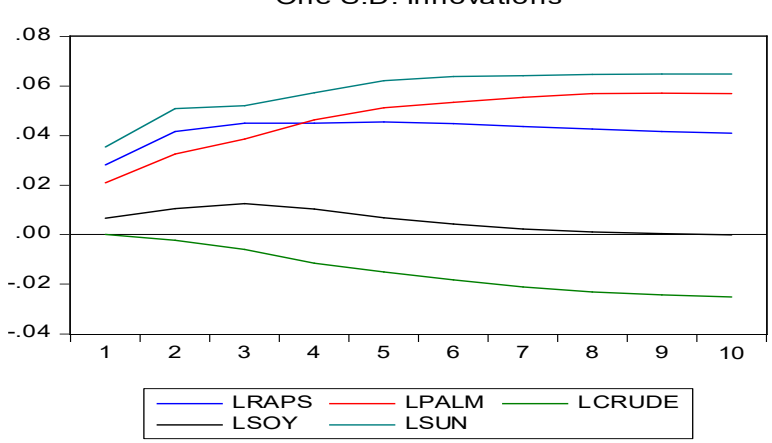

Figure 1. Responses of a variable price toward another variable price

The impulse response function (IRF) shows the result of a variable price resulted from the shock of another variable price. The response of a variable price to another variable price can be negative or positive. The result of the IRF is presented in Figure 1. Figure 1 reveals that 
responses in LPOP, LROP, LSFOP, LCOP, and LSOP steadily fluctuated along 10 months after the actual month. In addition, the responses of LPOP, LSFOP, LROP, and LSOP had negative trends because of LCOP shock. It implies that an increase in LCOP led to decreases in vegetable oil prices.

Variance Decomposition analysis depicts the relative importance of each variable in the system because of shock. This analysis is useful to predict the percentage contribution of each
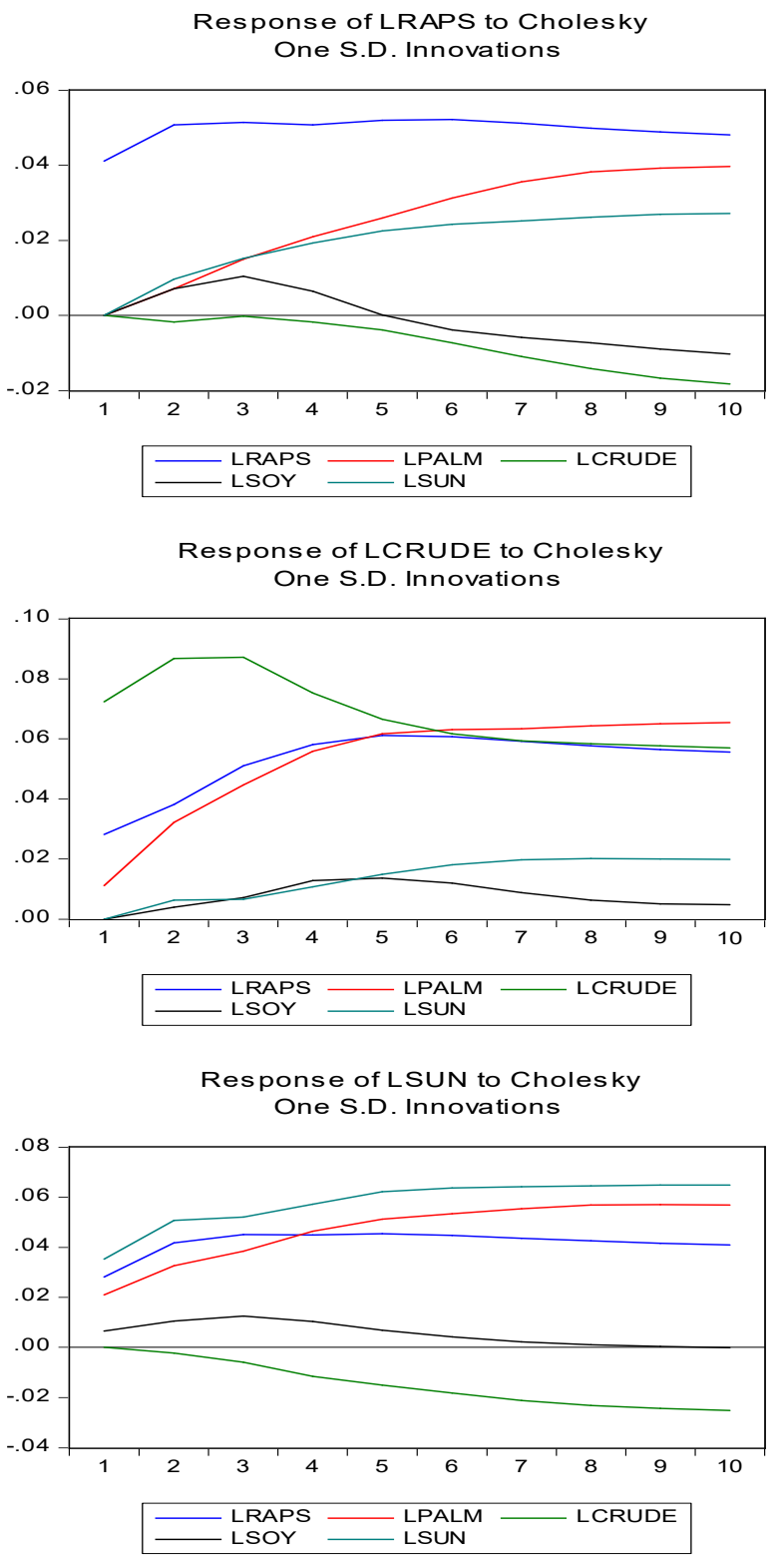

variable in the system so that it can be examined the source of variability from the model.

The result of FEDV is presented in Figure 2. It implies that the responses of vegetable oil prices are much explained by the variability of its price and LPOP. LPOP had a significant contribution to explain the variability of the other vegetable oil prices. In 10 months after the actual month, LROP, LSOP, LSFOP were explained by LPOP of $21.04 \%, \quad 51.08 \%$, and $29.61 \%$ respectively.
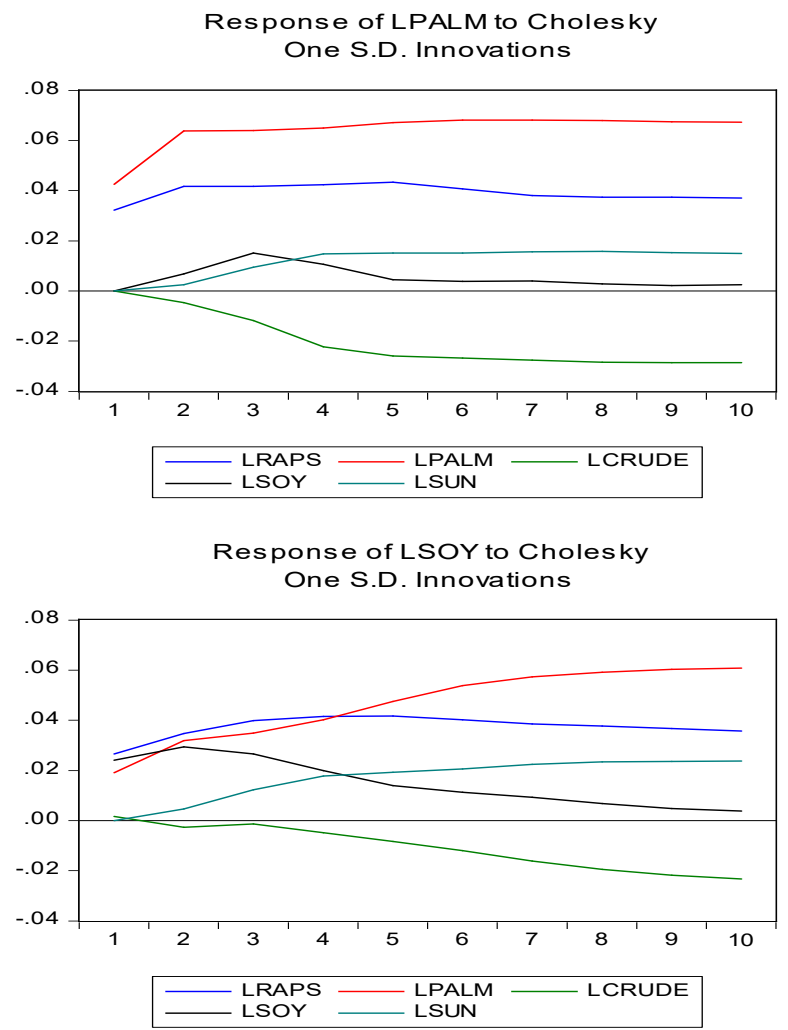

Figure 2. Result of FEDV

\section{Conclusion}

Among the all vegetable oils price, the average price of palm oil is the lowest which can imply that palm oil was the most competitive vegetable oil. The correlation of oil prices reveals that vegetable oils and crude oil have a high correlation. All correlation coefficients among prices are above $80 \%$. Rapeseed oil and soybean have the highest coefficient which means the 
increasing of rapeseed oil price will be followed by the soybean oil price. The relationship among vegetable oils was higher than the relationship between vegetable oils and crude oil. It meant that the strong substitution relationship experienced among those vegetable oils. That biofuels produced by vegetable oils are an almost perfect substitute for fossil fuels. The market price of biofuels should, therefore, be strongly dependent on the market price for gasoline and diesel.

The existence of a long-run relationship among oil prices was conducted using bivariate and multivariate Johansen's cointegration test. The results reveal a cointegration relationship between the LCOP and LROP. In addition, the cointegration relationship appears among vegetable oil prices. There is one linear combination among oil prices in the long run, despite deviation from equilibrium levels in the short-run. It also implies that information flow (price transmission) occurs among the oil prices. After examining the cointegration, the analysis continues to examine the appropriate lag for estimating VECM. The test reveals appropriate lag for the model was the third lag. The number of lag criteria means the implication of all variable oil prices which are used in the equation influence each other not only in the same period but those variables which are interrelated to three previous periods.

All of the ECT coefficients were negative, but only LROP and LSOP which had significant error correction term (ECT). The negative ECT value will show how quickly the adjustment is needed in a short run disequilibrium towards longrun equilibrium. The number of ECT coefficient of LSOP implies that the speed of adjustment towards the equilibrium takes place by $0.25 \%$ per period. The insignificant ECT coefficient of LPOP implies that the changes in LPOP were not significantly influenced by LCOP, LROP, LSOP, and LSFOP or It might be influenced by other factors. To give more explanation about VECM estimation, the result of the Granger causality test is presented and the result shows that vegetable oil prices do Granger cause crude oil price. In other words, it can be concluded that there was a shortrun causality from vegetable oil prices significantly influenced the crude oil price in the short run.

The impulse response function (IRF) shows the result of a variable price resulted from the shock of another variable price. The response of a variable price to another variable price can be negative or positive. The responses in LPOP, LROP, LSFOP, LCOP, and LSOP steadily fluctuated along 10 months after the actual month. In addition, the responses of LPOP, LSFOP, LROP, and LSOP had negative trends because of LCOP shock. It implies that an increase in LCOP led to decreases in vegetable oil prices. Variance Decomposition analysis depicts the relative importance of each variable in the system because of shock. This analysis is useful to predict the percentage contribution of each variable in the system so that it can be examined the source of variability from the model. It implies that the responses of vegetable oil prices much explained by the variability of its price and LPOP. LPOP had a significant contribution to explain the variability of the other vegetable oil prices. In 10 months after the actual month, LROP, LSOP, LSFOP were explained by LPOP of $21.04 \%, 51.08 \%$, and $29.61 \%$ respectively.

\section{References}

Aji, B. W. P. (2010). Analisis Integrasi Harga Minyak Bumi, Minyak Kedelai, Cpo, Minyak Goreng Domestik Dan Tandan Buah Segar Kelapa Sawit. In Institut Pertanian Bogor. Bogor Agricultural University.

Amna Awad Abdel Hameed, \& Fatimah Mohamed Arshad. (2009). The Impact Of Petroleum Prices On Vegetable Oils Prices: Evidence From Cointegration Tests. Oil Palm Industry Economic Journal, 31-40. http://econ.upm.edu.my/ fatimah/Amnafatimah-petrol-palm-oil-price.pdf

Barrett, C. B., \& Li, J. R. (2002). Distinguishing between equilibrium and integration in spatial price analysis. American Journal of Agricultural Economics, 84(2), 292-307. https://doi.org/10.1111/1467-8276.00298

Bergmann, D., O'Connor, D., \& Thümmel, A. (2016). An analysis of price and volatility transmission in butter, palm oil and crude oil markets. Agricultural and Food Economics, 4(1). https://doi.org/10.1186/s40100-016-0067-4

Buyung, Syechalad, N., Masbar, R., \& Nasir, M. (2017). The Analysis af Factors Affecting CPO Export Price. European Journal of Accounting Auditing and Finance Research, 5(7), 17-29. 
Fadila, J. D., Kusnadi, N., \& Rifin, A. (2014). Analisis Pergerakan Harga Internasional Minyak Bumi, CPO dan Kedelai dengan Pendekatan VECM. Prosiding Perhepi 2014, $1-12$. https://doi.org/10.4324/9781315853178

Hassan, A., \& Balu, N. (2016). Examining the Long-term Relationships between the Prices of Palm Oil and Soyabean Oil , Palm Oil Production and Export: Cointegration and Causality. Oil Palm Industry Economic Journal, 16(1),

31-37. http://palmoilis.mpob.gov.my/publications/ OPIEJ/opiejv16n1-ain.pdf

Manik, M., Napitupulu, D., \& Elwamendri. (2018). Analisis Integrasi Harga Minyak Kelapa Sawit dan Harga Minyak Kedelai di Pasar Internasional. Jurnal Ilmiah Sosial Ekonomika Bisnis, 21(2), 65-75. https://doi.org/10.22437/jiseb.v21i2.8608

Manurung, I., Bruemmer, B., \& Kopp, T. (2019). Price Transmission in International Crude Palm Oil Markets: The Effects of Export Tax of Indonesia. Advances in Economics, Business and Management Research, 98(January). https://doi.org/10.2991/icot19.2019.15

Paramita, D. P. R., Nuryantono, N., \& Achsani, N. A. (2015). Analisis Faktor Yang Mempengengaruhi Harga dan dan Integrasi Harga Olein. Jurnal Ekonomi Dan Kebijakan Pembangunan, 4(1), 28-48.

Paspi, T. R. (2018a). Analisis Harga Minyak Sawit Dunia: Vol. IV (Issue 29).

Paspi, T. R. (2018b). Anomali Harga CPO Dunia: Vol. IV (Issue 41).

Pokrivcak, J., \& Rajcaaniova, M. (2011). Crude oil price variability and its impact on ethanol prices. Agricultural Economics, 57(8), 394-403.

Rifai, N., Syaukat, Y., Siregar, H., \& Sa'id, E. G.. (2017). Dampak Pengembangan Produk Turunan Minyak Sawit terhadap Peningkatan Ekspor Produk Minyak Sawit ke Pasar Amerika Serikat. Jurnal Agro Ekonomi, 32(2), 107-125. https://doi.org/10.21082/jae.v32n2.2014.10 7-125

Rifin, A. (2009). Price Linkage between International Price of Crude Palm Oil
(CPO) and Cooking Oil Price in Indonesia. International Association of Agricultural Economists Conference, 16-22. http://ageconsearch.umn.edu/bitstream/508 28/2/Price Linkage_Revision.pdf

Rosa, F., Vasciaveo, M., \& Weaver, R. D. (2014). Agricultural and Oil Commodities: Price Transmission and Market Integration between US and Italy. Bio-Based and Applied Economics, 3(2), 93-117. https://doi.org/10.13128/BAE-12944

Saghaian, S. H. (2010). The Impact of the Oil Sector on Commodity Prices: Correlation or Causation? Journal of Agricultural and Applied Economics, 42(3), 477-485. https://doi.org/10.1017/s107407080000366 7

Saghaian, S., Nemati, M., Walters, C., \& Chen, B. (2018). Asymmetric price volatility transmission between U.S. Biofuel, Corn, and Oil Markets. Journal of Agricultural and Resource Economics.

Sendhil, R., Sundaramoorthy, C., Venkatesh, P., \& Thomas, L. (2014). Testing market integration and convergence to the law of one price in Indian onions. African Journal of Agricultural Research, 9(40), 29752984.

https://doi.org/10.5897/ajar2013.8037

Sinha, R. K. P. and K. (2015). Spatial Market Integration among Major Coffee Markets in India. Journal of the Indian Society of Agricultural Statistics, 69(3), 281-287.

Songsiengchai, P., Sidique, S. F., Djama, M., \& Azman-Saini, W. N. W. (2018). A cointegration analysis of crude palm oil price in Thailand. E3S Web of Conferences, 52 , 00035 . https://doi.org/10.1051/e3sconf/201852000 35

Songsiengchai, P., Sidique, S. F., Djama, M., \& Azman-Saini, W. N. W. (2020). Asymmetric adjustments in the thai palm oil market. Kasetsart Journal of Social Sciences, $\quad 41(1), \quad 220-225$. https://doi.org/10.1016/j.kjss.2018.05.018

Yu, T.-H., Bessler, D. A., \& Fuller, S. (2006). Cointegration and Causality Analysis of World Vegetable Oil and Crude Oil Prices. American Agricultural Economics Association Annual Meeting, July(May 
2014),

$23-26$.

https://doi.org/10.1017/CBO97811074153

24.004 